\title{
Influence of seasonally deposited phytodetritus on benthic foraminiferal populations in the bathyal northeast Atlantic: the species response
}

\author{
A. J. Gooday ${ }^{1}$, P. J. D. Lambshead ${ }^{2,}$ \\ ${ }^{1}$ Institute of Oceanographic Sciences, Deacon Laboratory, Wormley, Godalming, Surrey GU8 5UB, United Kingdom \\ ${ }^{2}$ Department of Zoology, British Museum (Natural History), Cromwell Road, London SW7 5BD, United Kingdom
}

\begin{abstract}
Cores were obtained with a multiple corer at a bathyal site (1320 to $1360 \mathrm{~m}$ depth) in the Porcupine Seabight during April and July 1982. In July (but not April) the sediment surface was overlain by a layer of phytodetritus, material rapidly sedimented from the euphotic zone following the spring bloom. The phytodetrital fraction of samples $\left(0\right.$ to $1 \mathrm{~cm}$ layer of subcores; $3.46 \mathrm{~cm}^{2}$ surface area) removed from the July cores harboured dense, low-diversity populations of benthic foraminifers which resembled the phytodetritus-dwelling assemblages already described from the much deeper (4550 m) BIOTRANS site in the northeast Atlantic. Our new observations consolidate the view that phytodetritus is a microhabitat for some deep-sea benthic foraminiferal species. The bathyal populations were dominated by Alabaminella weddellensis (75\% of total) and also included Epistominella exigua and Tinogullmia sp. nov. These 3 species occurred also in the BiOTRANS phytodetrital assemblages. The April samples and the total July samples (phytodetritus plus sediment fractions) yielded diverse foraminiferal populations of similar density and species richness. However, there were some important taxonomic differences. In particular, the 8 species consistently present in the phytodetritus were significantly more abundant in the July samples, while the most common species in the April samples (Orammina sp. nov. A) was entirely absent during July. We argue that the influence of phytodetritus, rather than spatial variability (patchiness), was responsible for some of the differences in species abundances. Other species, however, maintain more stable population densities. Our results suggest that deep-sea benthic foraminifers, like those living in shallow water, probably display a variety of life-history strategies and population dynamics.
\end{abstract}

\section{INTRODUCTION}

The delivery of organic material to the food-limited deep-sea benthic ecosystem is a central topic in biological oceanography (Angel 1984, Fowler \& Knauer 1986, Bruland et al. 1989). One potentially important pathway is provided by rapidly sedimented phytoplankton blooms (Takahashi 1986) which accumulate during the spring and early summer on the sea-floor as a layer of 'phytodetritus'. This material was first reported in sediment cores and bottom photographs taken at depths of 1000 to $4500 \mathrm{~m}$ in the Porcupine Seabight (an area centred around $51^{\circ} 30^{\prime} \mathrm{N} ; 13^{\circ} 00^{\prime} \mathrm{W}$ ) and on the adjacent abyssal plain (Billett et al. 1983, Lampitt 1985, Rice et al. 1986). Elsewhere in the northeast Atlantic it has been observed in the Rockall Trough (Barnett et al. 1982), the northern Bay of Biscay (Sibuet 1984, p. 105,

\footnotetext{
- Addressee for correspondence
}

1987) and a more centrally oceanic site $\left(47^{\circ} 00^{\prime}\right.$ to $47^{\circ} 30^{\prime} \mathrm{N} ; 19$ to $20^{\circ} \mathrm{W}$ ) sampled intensively during the German BIOTRANS programme (Riemann 1989, Thiel et al, in press). Similar material has been recorded at bathyal and abyssal depths in the northwest Atlantic (Aller \& Aller 1986, Grassle \& Morse-Porteous 1987) and photographed at $4469 \mathrm{~m}$ in the eastern Pacific (Gardner et al. 1984). Phytodetritus is known to be ingested by deposit-feeding echinoderms (Billett et al 1988) and other megabenthic animals (Thiel et al. in press). Evidence from the BIOTRANS site $(4550 \mathrm{~m}$ depth) indicates that it is also degraded rapidly by deep-sea bacterial populations (Lochte \& Turley 1988) and colonised and eaten by small benthic foraminifers (Gooday 1988a). The present paper explores further the impact of this seasonally deposited detrital material on deep-sea foraminiferal populations.

Gooday (1986) described abundant (> 1000 'living' i.e. rose Bengal stained, individuals per $10 \mathrm{~cm}^{2}$ ) and 
diverse ( $>90$ species) foraminiferal assemblages in smal.] samples ( $3.46 \mathrm{~cm}^{2}$ surface area) collected in April 1982 from bathyal depths (around $1340 \mathrm{~m}$ ) in the Porcupine Seabight. These samples were taken with a multiplecorer while the spring bloom was occurring in the surface waters (Billett et al. 1983) but before the resulting phytodetrital material had arrived on the sea bed. A. second set of cores was obtained in approximately the same position during July 1982 when the sediment surface was overlain by a layer of phytodetritus some $5 \mathrm{~mm}$ thick. In this paper we compare the foraminiferal populations, and their constituent species, from the April (pre-detritus deposition) and July (post-detritus deposition) samples. Two main questions are addressed. First, does the colonisation of phytodetritus by benthic foraminifers, which Gooday (1988a) described from BIOTRANS material, also occur at this much shallower site? Second, what effect, if any, does the presence of phytodetritus have on the overall abundance of benthic foraminiferal populations and species?

\section{MATERIALS AND METHODS}

The samples were collected in the Porcupine Seabight using a multiple-corer, which recovers simultaneously up to 12 cores with the sediment-water interface virtually undisturbed (Barnett et al. 1984). Cores obtained on 10 April 1982 at Stn 51502 ('Challenger' Cruise 6/82) and on 22 to 23 July 1982 at Stn 51615 ('Challenger' Cruise 10/82) form the basis for this study. The stations were located within the area $51^{\circ} 35^{\prime}$ to $51^{\circ} 36^{\prime} \mathrm{N}, 12^{\circ} 59^{\prime}$ to $13^{\circ} 01^{\prime} \mathrm{W}$ and the depth range 1320 to $1361 \mathrm{~m}$ (Table 1; Gooday 1986 Table 1). At each station, the corer was deployed 6 times. On each occasion, 4 cores (a to d) were selected at random and subsampled using a $20 \mathrm{ml}$ syringe $\left(3.46 \mathrm{~cm}^{2}\right.$ crosssectional areal modified by cutting off the end and sharpening the cut edge. The subcores were later cut into $1 \mathrm{~cm}$ thick horizontal slices down to a depth of $5 \mathrm{~cm}$ and each layer fixed and stored separately in $4 \%$ formaldehyde buffered with sodium borate. Only data from the 0 to $1 \mathrm{~cm}$ layer (including phytodetritus) of the subcores are considered in this paper.

In the laboratory the sediment was gently washed through a series of small $(75 \mathrm{~mm}$ diameter) sieves $(500$. 150. 106, 63, $45 \mu \mathrm{m}$ meshes) using filtered tap water, and then stained in rose Bengal for several hours. The sieve residues were sorted wet in a petri dish under a stereomicroscope for metazoans and foraminifers. Larger, hard-shelled foraminifers were mounted dry on micropalaeontological slides. Smaller species, including those with soft, flexible tests (Gooday 1986), were either stored in anhydrous glycerine in cavity slides, or mounted permanently in anhydrous glycerine on flat glass slides under supported cover slips (Gooday 1988b).

Phytodetritus was present on the surfaces of all cores collected during July. However, its importance as a foraminiferal habitat was realized only after 4 of the 9 subcores from this station had been already sorted. For the remaining 5 subcores (51615 nos. 1a, 1b, 5c, 5d, 6b), and an additional subcore (5b) which was examined for metazoans (Table 1), phytodetritus was picked out from the stained residues. This material forms coherent, gelatinous lumps ('aggregates') which were gently teased apart using fine entomological pins to extract the inhabitants. These were stored as described above. - Picking phytodetrital aggregates from sieve residues clearly was not an ideal procedure since the possibility of organisms being either incorporated into, or washed out of the phytodetritus during sample collection, stor-

Table 1. Location and fate of samples obtained at $\operatorname{Stn} 51615$ (22 to 23 July 1982). Samples consisted of the $0-1 \mathrm{~cm}$ layer of subcores taken from cores collected with the multiple corer They contained phytodetritus and sediment which were separated in sieve residues. Equivalent data for Stn 51502 (10 April 1982) are given by Gooday (1986, Table 1)

\begin{tabular}{|c|c|c|c|c|c|c|c|c|}
\hline \multirow[t]{2}{*}{ Deployment } & \multicolumn{2}{|c|}{ Position } & \multirow[t]{2}{*}{$\begin{array}{c}\text { Depth } \\
(\mathrm{m})\end{array}$} & \multirow[t]{2}{*}{ Subcore } & \multicolumn{2}{|c|}{$\begin{array}{l}\text { Sediment fraction sorted } \\
\text { for }\end{array}$} & \multicolumn{2}{|c|}{$\begin{array}{c}\text { Phytodetrital fraction } \\
\text { sorted for: }\end{array}$} \\
\hline & ${ }^{\circ} \mathrm{N}$ & ${ }^{\circ} \mathrm{W}$ & & & Eoramınifers & metazoans & foraminifers & metazoans \\
\hline \multirow[t]{2}{*}{1} & $51^{\circ} 36.0^{\circ}$ & $12^{\circ} 59.3^{\prime}$ & 1345 & a & $x$ & $\mathrm{x}$ & $x$ & $\mathrm{x}$ \\
\hline & & & & b & $x$ & $x$ & $x$ & $x$ \\
\hline \multirow[t]{4}{*}{4} & $51^{\circ} 35.3^{\prime}$ & $12^{\circ} 59.8^{\prime}$ & 1361 & a & & $x$ & & \\
\hline & & & & b & $x$ & $\mathrm{x}$ & & \\
\hline & & & & $c$ & $x$ & $\mathrm{x}$ & & \\
\hline & & & & d & $\mathrm{x}$ & $\mathrm{x}$ & & \\
\hline \multirow[t]{4}{*}{5} & $51^{\circ} 35.3^{\prime}$ & $13^{\circ} 00.5^{\prime}$ & 1361 & a & & $\mathrm{x}$ & & \\
\hline & & & & b & & $\mathrm{x}$ & $x$ & $\mathrm{x}$ \\
\hline & & & & c & $x$ & $x$ & $x$ & $x$ \\
\hline & & & & $d$ & $x$ & $\mathrm{x}$ & $x$ & $x$ \\
\hline \multirow[t]{2}{*}{6} & $51^{2} 35.1^{\prime}$ & $13^{\circ} 00.6^{\prime}$ & 1356 & a & $x$ & $\mathrm{x}$ & & \\
\hline & & & & b & $x$ & $x$ & $x$ & $\mathrm{x}$ \\
\hline
\end{tabular}


age and sieving could not be eliminated. A few species which occurred only rarely and sporadically in the phytodetrital fractions (Table 3) may have become attached to aggregates accidentally. However, we believe this to be a minor source of error for the following reasons: (1) The phytodetritus formed coherent, gelatinous aggregates in which the foraminifers were often deeply embedded and from which they were rather difficult to extract. (2) If the association between foraminifers and phytodetritus were accidental, then specimens with rough, agglutinated test walls would tend to become entangled preferentially. In fact, such specimens were common only in the sediment fraction whereas the dominant phytodetrital inhabitants were rotaliins with generally smooth, glassy surfaces. (3) One species dominated the phytodetrital assemblages. There is no obvious reason why this species (Alabaminella weddellensis) should become associated accidentally with phytodetritus while other calcareous species, for example Cassidulina teretis, Nonionella iridea (which are abundant in the sediment at Stn 51615), did not. (4) The taxonomic composition of the phytodetrital assemblages showed a high degree of consistency (Table 3) which is unlikely to have arisen had these assemblages merely been artifacts of the sampling process. (5) A. weddellensis, and 2 other species, were present in phytodetritus from our samples and from the BIOTRANS site. Again, this coincidence is unlikely to have arisen by chance. (6) Finally, a sample of phytodetritus (and some admixed sediment), pipetted from the surface of a core obtained at Stn 51615, contained foraminifers dominated by species which also occurred in the phytodetrital aggregates extracted from our sieve residues (see below and Table4). This indicates strongly that our detrital assemblages were not artifacts.

A transfer of foraminifers from the phytodetritus to the sediment is more likely, particularly during sample sieving. Unfortunately, the extent of this problem is impossible to assess and therefore we do not regard specimens extracted from the sediment residues (the 'sediment fraction') as constituting a distinct assemblage. While we report some data from the sediment fraction (Tables 5 to 7 and 9), our comparison of the foraminiferal assemblages in the April and July samples is based mainly on total populations.

Criteria for distinguishing live and dead foraminifers were discussed by Gooday $(1986,1988)$. For the present study, most of the specimens which stained red with rose Bengal were examined in glycerol (which renders the test more transparent) under a highpowered compound microscope to ensure that they contained material which resembled fresh protoplasm. However, it is impossible to be certain that specimens containing stained protoplasm were alive when cap- tured. Stainable protoplasm can persist for weeks or months after a foraminifer dies (Boltovskoy \& Lena 1970). Bernhard (1988) has compared the proportion of rose Bengal stained specimens in her Antarctic samples to the proportion of live specimens as determined by ATP assay, As many as half the specimens which stained with rose Bengal were dead. In our material we therefore regard rose Bengal stained tests as being merely 'stained'. When collected they were either alive or had died fairly recently and still contained fresh protoplasm.

For testing the significance of means we used a t-test assuming unequal variances. For testing between variances we used an F-test. Subcores are hereafter referred to as samples.

\section{RESULTS}

A considerable effort has been made to identify accurately the abundant species in our samples. Type material housed in the British Museum (Natural History) was examined where necessary. Species which are indicated as new in Tables 7 to 9 will be described elsewhere (Gooday unpubl.). Other important species are characterised and illustrated either by Gooday (1986, Figs. 10, 11, Table 5) or in Fig. 1 and Table 2 of the present paper. With one exception (Alabaminella weddellensis = Epistominella levicula) the names used in this paper are consistent with those used by Gooday (1986). The names and authorships of species mentioned in this paper are listed in the Appendix.

Our suprageneric classification follows Loeblich \& Tappan (1988).

\section{Phytodetrital populations}

The phytodetrital fractions (each ca 0.5 to $1.0 \mathrm{ml}$ in volume) from 6 July samples yielded 104 to 260 stained benthic foraminifers which represented $97.1 \%$ of all colonising organisms (Table 3 ). Most ( $87.0 \%$ ) of the 979 specimens belonged to the suborder Rotaliina. Other higher taxa represented were the suborders Allogromiina $(4.1 \%)$, Lagenina $(2.6 \%)$, Textulariina, superfamilies Spiroplectamminacea $(5 \%)$, Trochamminacea (1\%), and Astrorhizacea, family Saccamminidae $(0.3 \%)$. A total of 13 species was recognised, although only 8 of these occurred in 4 or more samples (Table 3 ). The remaining 5 were rare and possibly contaminants from the underlying sediment (see above). One species, Alabaminella weddellensis, was consistently dominant and accounted for $75 \%$ of all specimens. Most species which occurred in the phytodetritus were found also in the sediment fractions (Table 

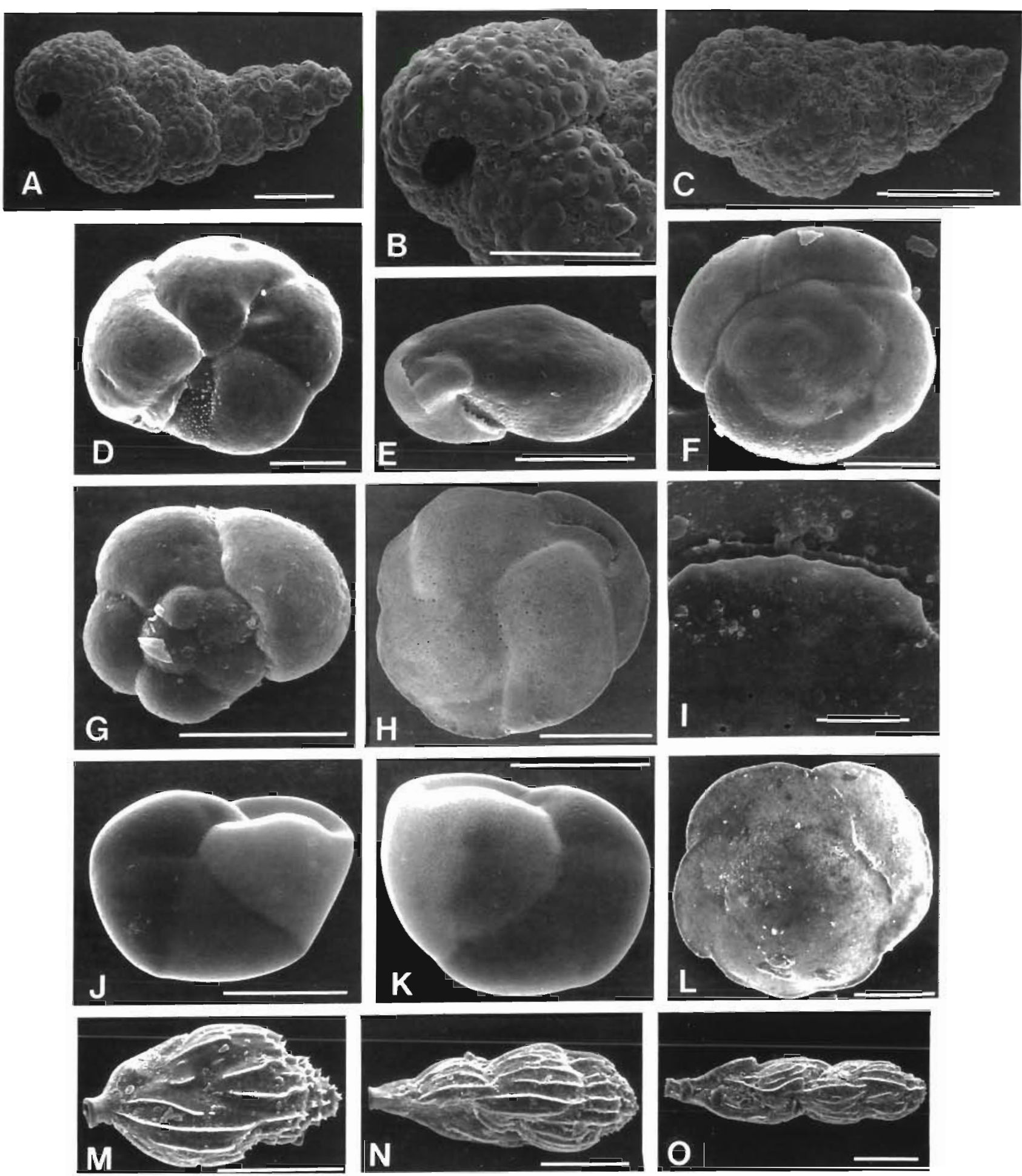

Fig. 1. SEM photographs of foraminiferal species common in the April and July samples. (A) to (C) Morulaeplecta sp. nov.; (D) to (F) Alabaminella weddellensis showing involute surface, side view, and evolute surface respectively; (G) ?Alabaminella sp. evolute side: $(\mathrm{H})$, (I) Cassidulina teretis showing entire test and detail of aperture; $(\mathrm{J}),(\mathrm{K})$ Epistonella exigua; (L) Gavinulinopsis lobatulus: (M) to (O) Trifarina pauperata, showing the progressively larger and more elongate specimens. Scale bars = 50 um $(\mathrm{A}$ to G, J, K): $100 \mu \mathrm{m}(\mathrm{H}, \mathrm{L}$ to O): $20 \mu \mathrm{m}$ (I) 
Table 2. Taxonomic comments on important species occurring at Stns 51502 (April) and 51615 (July)

\begin{tabular}{|c|c|c|}
\hline Suborder and species & Original description and comments & Illustrations \\
\hline \multicolumn{3}{|l|}{ Suborder Textulariina } \\
\hline Morulaeplecta sp. nov. & $\begin{array}{l}\text { Tiny textularinid ( } \mathrm{L}=60-160 \mathrm{um} \text { long) with early chambers streptospi- } \\
\text { rally coiled around proloculus and after chambers arranged biserially. } \\
\text { Differs in several respects from } M \text {. bulbosa Höglund: test is more } \\
\text { strongly flared, wall is composed largely of coccoliths rather than min- } \\
\text { eral grains, and aperture is oval areal opening near base of final } \\
\text { chamber }\end{array}$ & Fig. $1 \mathrm{~A}-\mathrm{C}$ \\
\hline \multicolumn{3}{|l|}{ Suborder Rotaliina } \\
\hline $\begin{array}{l}\text { Alabaminella weddellensis } \\
\text { (Earland) }\end{array}$ & $\begin{array}{l}=\text { Eponides weddellensis Earland (1936, p. 57, Pl. 1, Figs. 65-67). } \\
\text { Gooday (1986) identified this species as Epistominella levicula Resig. } \\
\text { Van der Zwaan (1980, Pl. 1, Fig. 1) illustrates typical pustulate specimen } \\
\text { as Eponides leviculus. Present identification based on comparison with } \\
\text { BIOTRANS specimens and type material (Royal Museum of Scotland); } \\
\text { generic placement follows Loeblich \& Tappan (1988, p. 548). See also } \\
\text { Table } 10\end{array}$ & Figs. 1D-F, 3A-D \\
\hline ? Albaminella sp. & $\begin{array}{l}\text { Test } 40-120 \mu \mathrm{m}(\overline{\mathrm{x}}=79 \pm 18 \mu \mathrm{m}, \mathrm{n}=45 \text { ) diameter with chambers } \\
\text { increasing more rapidly in size than in } A \text {. weddellensis. }\end{array}$ & Fig. 1G \\
\hline Cassidulina teretis Tappan & $\begin{array}{l}\text { See Tappan (1951,p. } 7, \mathrm{Pl} .1, \text { Fig. } 30) \text {. Our specimens identified accord- } \\
\text { ing to criteria of Mackensen \& Hald (1988). Diameter in our material }= \\
50-230 \mu \mathrm{m}(\overline{\mathrm{x}}=116 \pm 42 \mu \mathrm{m}, \mathrm{n}=302)\end{array}$ & Fig. $1 \mathrm{H}, \mathrm{I}$ \\
\hline $\begin{array}{l}\text { Epistominella exigua } \\
\text { (Brady) }\end{array}$ & 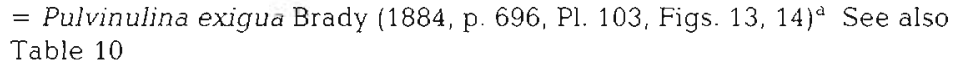 & Fig. 1J, K \\
\hline $\begin{array}{l}\text { Gavinulinopsis lobatulus } \\
\text { (Parr) }\end{array}$ & $\begin{array}{l}=\text { Discorbis lobatulus Parr }(1950, \text { p. 354, Pl. 13, Figs. 23-25). Our } \\
\text { specimens are indentical to those illustrated by Weston }(1985, \text { Pl. } 2 \text {, } \\
\text { Fig. 2), which were also from the Porcupine Seabight }\end{array}$ & Fig. 1L \\
\hline $\begin{array}{l}\text { Trifarina pauperata } \\
\text { (Heron-Allen \& Earland) }\end{array}$ & $\begin{array}{l}\text { = Uvigerina angulosa Williamson var. pauperata Heron-Allen \& Earland } \\
\text { (1932, p. } 398, \text { Pl. } 12 \text {. Figs. } 40-43)^{a} \text { Our specimens are closely similar to } \\
\text { original material from } 454-1036 \mathrm{~m} \text { in the Falkland Islands area. This } \\
\text { variety was given specific status by Parr }(1950, \text { p. } 341)\end{array}$ & Fig. $1 \mathrm{M}-\mathrm{O}$ \\
\hline \multicolumn{3}{|l|}{ Suborder Lagenina } \\
\hline $\begin{array}{l}\text { Parafissurina fusuliformis } \\
\text { (Loeblich \& Tappan) }\end{array}$ & $\begin{array}{l}\text { Loeblich \& Tappan }(1953, \mathrm{Pl} .14, \text { Figs. } 18-19) \text {. A tiny, elongate species, } \\
\text { usually }<100 \mu \mathrm{m} \text { long, generally occurs attached parasitically to tests of } \\
\text { A. weddellensis. Our specimens closely resemble illustrations of Jones } \\
(1984, \text { Pl. 6, Fig. 7-8) and Ward \& Webb }(1986, \text { Pl 3, Fig. 15) }\end{array}$ & \\
\hline
\end{tabular}

8). However, 2 species, ?Alabaminella sp. A and Parafissurina fusuliformis (the latter usually was attached epiparasitically to the test of $A$. weddellensis), were concentrated largely in the phytodetritus.

The foraminifers varied in size from 40 to $300 \mu \mathrm{m}$ and therefore fell within the meiofaunal size range. The most abundant species, Alabaminella weddellensis, was 40 to $160 \mu \mathrm{m}$ (mean $88.0 \pm 21.7 \mu \mathrm{m}, \mathrm{n}=750$ ) in diameter, half the specimens were smaller than $90 \mu \mathrm{m}$ and ca $80 \%$ were smaller than $110 \mu \mathrm{m}$ (Fig. 2).

An additional sample ( 1 to $2 \mathrm{ml}$ volume) consisting of phytodetritus and some sediment (collected and made available by Dr R. S. Lampitt) was also examined. It had been removed from the surface of a core (Stn 51615 Deployment 1) using a Pasteur pipette. This sample yielded 157 stained benthic foraminifera of which 20 were found within lumps of sediment and 5 (all Tinogullmia sp. nov.) inside the moults of crustaceans ( $<1 \mathrm{~mm}$ in length), probably harpacticoid copepods
(Gooday in press) (Table 4). The remaining 132 specimens occurred within aggregates of phytodetritus or lumps consisting of phytodetritus mixed with sediment. This sample contained more species (19) than phytodetritus extracted from the sieve residues. Also, Alabaminella weddellensis constituted $<50 \%$ of the total numbers of specimens. These differences probably reflect the fact that the sample comprised an unsieved and unwashed mixture of phytodetritus and superficial sediment.

\section{Total and sediment populations}

The April samples yielded 253 to 491 (mean $385 \pm$ 79) stained benthic foraminifers and the July samples yielded 356 to 1218 (mean $713 \pm 218$ ) specimens of which 161 to 958 (mean $474 \pm 216$ ) were found in the sediment fractions (Table 5). None of these mean val- 
Table 3. Species extracted from the phytodetrital fractions of Sin 51615 (July) samples. Those occurring in 4 or more fractions are indicated by an asterisk. Except for those in the final column and bottom 2 lines, all values are percentages

\begin{tabular}{|c|c|c|c|c|c|c|c|c|}
\hline \multirow[t]{2}{*}{ Species } & \multicolumn{6}{|c|}{ Fraction } & \multirow{2}{*}{$\begin{array}{c}\text { Overall } \\
\%\end{array}$} & \multirow{2}{*}{$\begin{array}{l}\text { Mean numbe } \\
\text { per sample } \\
\quad \pm \mathrm{SD}\end{array}$} \\
\hline & $1 \mathrm{a}$ & $1 \mathrm{~b}$ & $5 b$ & $5 c$ & $5 \mathrm{~d}$ & $6 \mathrm{~b}$ & & \\
\hline \multicolumn{9}{|l|}{ Suborder Allogromiina } \\
\hline - Tinogullmia sp. nov. A & 5.43 & 3.85 & 8.13 & 0.53 & 5.00 & 0.96 & 3.88 & $6.2 \pm 4.3$ \\
\hline Inciet. & - & - & - & 1.06 & - & - & 0.20 & $0.3 \pm 0.7$ \\
\hline \multicolumn{9}{|l|}{ Suborder Textulariina } \\
\hline Saccamminid sp. & - & - & - & - & 1.67 & 0.96 & 0.31 & $0.5 \pm 0.8$ \\
\hline 'P. aff. pygmaea & 2.17 & - & - & 1.06 & 1.67 & 1.92 & 1.02 & $1.7 \pm 1.4$ \\
\hline - Morulaeplecta sp. nov A & 6.52 & 3.85 & 3.25 & 6.91 & 4.12 & 4.81 & 5.01 & $8.2 \pm 3.6$ \\
\hline \multicolumn{9}{|l|}{ Suborder Rotaliina } \\
\hline - A. weddellensis & 71.44 & 75.38 & 76.42 & 73.40 & 68.33 & 77.88 & 74.51 & $120.5 \pm 40.0$ \\
\hline -? Alabaminella sp. A. & 3.16 & 3.46 & 5.69 & 7.98 & 9.17 & 2.88 & 5.62 & $9.2 \pm 3.8$ \\
\hline Bolivina sp. A & 0.54 & - & - & - & - & - & 0.10 & $0.2 \pm 0.4$ \\
\hline C. teretis & - & - & 3.25 & 0.53 & 1.67 & - & 0.72 & $1.2 \pm 1.5$ \\
\hline C. pseudungerianus & - & - & & - & - & 0.96 & 0.10 & $0.2 \pm 0.4$ \\
\hline 'E. exigua & 5.43 & 2.69 & 0.81 & 2.66 & 3.33 & 1.92 & 2.96 & $4.8 \pm 3.0$ \\
\hline -G. lobatulus & 1.63 & 3.09 & 2.44 & 4.79 & 4.12 & 3.85 & 3.27 & $5.3 \pm 2.4$ \\
\hline G. subglobosa & - & 0.38 & - & - & - & - & 0.10 & $0.2 \pm 0.4$ \\
\hline Indet. & 1.63 & 0.38 & - & - & - & - & 0.41 & $0.7 \pm 1.1$ \\
\hline \multicolumn{9}{|l|}{ Suborder Lageniina } \\
\hline - $P$. fusuliformis & 1.63 & 4.62 & - & 1.06 & - & 3.85 & 2.55 & $4.2 \pm 5.0$ \\
\hline Total forams & 184 & 260 & 123 & 188 & 120 & 104 & 979 & $163.2 \pm 53.9$ \\
\hline Total Metazoans & - & 16 & 2 & 3 & 2 & 1 & 24 & $4.0 \pm 5.4$ \\
\hline
\end{tabular}

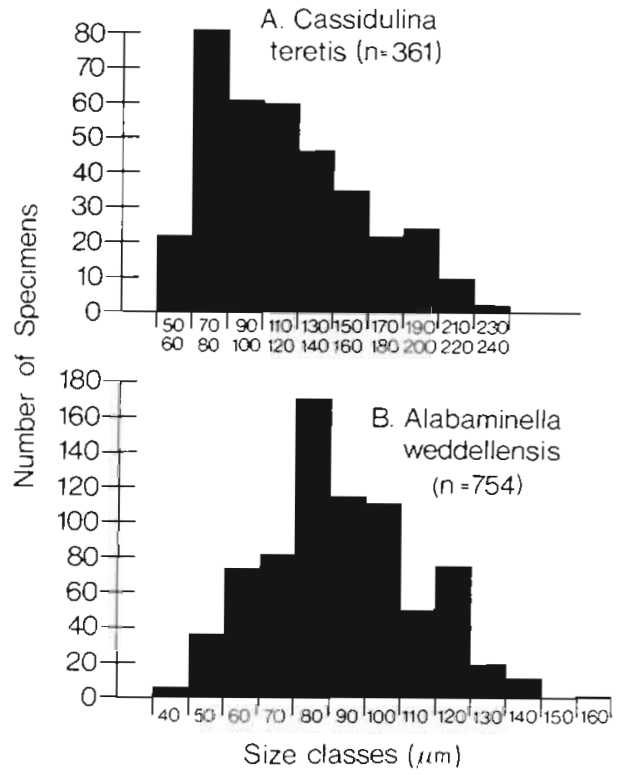

Fig. 2. Size distributions of Cassidulina teretis (specimens from sediment) and Alabaminella weddellensis (specimens from phytodetritus) in July samples

Les are significantly different ( $p>5 \%$ ). However, the total July populations have a significantly greater variance $(p<1 \%)$ than the April populations. Overall, foraminifers represent $59.0 \%$ (April), $56.7 \%$ (July sediment fraction) and $65.3 \%$ (July total population) of the meiofauna. Although the same higher taxa were present in both sets of samples (Table 6), Rotalina, the dominant taxon present in the phytodetritus, were more than twice as abundant in the total July populations (>50\%) as in the April populations (<25\%).

Both sets of samples contained about the same number of putative species, the overall range being between 58 and 94 per sample (Table 5). A total of 116 species were consistently recognised during this study. Table 7 shows the mean abundances of the top 30 species in the April samples compared with their abundances during July. Table 8 shows the equivalent data for the top 31 species in the July total populations. There are some notable differences between these populations. For example, the top 14 ranked species in the July populations were all significantly more abundant in July than in April (Table 8) while Ovammina sp nov., the top-ranked April species, was entirely absent during July (Table 7). The differences can be condensed into a list of 23 species divided into 3 groups.

Group A. Five species (including Ovammina sp. nov.) were significantly more abundant in the April populations than in the July total populations and sediment fractions (Table 7).

Group B. Ten species which occurred only (or mainly) in the sediment fractions were significantly more abundant in both the total July populations and the July sediment fractions than in the April samples (Table 8). 
Table 4. Abundance of species in sample pipetted from core surface (Stn 51615, Deployment 1). The number of specimens occurring in lumps of phytodetritus mixed with variable amounts of sediment, lumps of sediment without phytodetritus, and crustacean moults, are shown separately

\begin{tabular}{|c|c|c|c|}
\hline & Phytodetritus/sediment & Sediment only & Crustacean moults \\
\hline $\begin{array}{l}\text { Suborder Allgromiina } \\
\text { Tinogulimia sp. nov. A }\end{array}$ & $8 \quad(6.2 \%)$ & $3(15 \%)$ & 5 \\
\hline $\begin{array}{l}\text { Suborder Textulariina } \\
\text { Saccamminid sp. F } \\
\text { Saccamminid sp. G } \\
\text { A. glomeratum } \\
\text { P. aff. pygmaea } \\
\text { Morulaeplecta sp. nov. A } \\
\text { Indet }\end{array}$ & $\begin{array}{cc}2 & (1.5 \%) \\
1 & (0.8 \%) \\
1 & (0.8 \%) \\
1 & (0.8 \%) \\
23 & (17.8 \%) \\
- & \end{array}$ & $\begin{array}{l}- \\
- \\
- \\
2(10 \%) \\
2(10 \%) \\
1 \quad(5 \%)\end{array}$ & $\begin{array}{l}- \\
- \\
- \\
- \\
- \\
-\end{array}$ \\
\hline $\begin{array}{l}\text { Suborder Rotaliina } \\
\text { A. weddellensis } \\
\text { ? Alabaminella sp. A } \\
\text { Bolivina sp. A } \\
\text { Bulimina sp. } \\
\text { C. teretis } \\
\text { E. exigua } \\
\text { G. lobatulus } \\
\text { N. iridea } \\
\text { T pauperata }\end{array}$ & $\begin{array}{cc}62 & (48.4 \%) \\
9 & (7.0 \%) \\
1 & (0.8 \%) \\
1 & (0.8 \%) \\
1 & (0.8 \%) \\
6 & (4.6 \%) \\
6 & (4.6 \%) \\
- & \\
- & \end{array}$ & $\begin{array}{l}- \\
- \\
- \\
1 \quad(5 \%) \\
3(15 \%) \\
- \\
1 \quad(5 \%) \\
4(20 \%) \\
3(15 \%)\end{array}$ & $\begin{array}{l}- \\
- \\
- \\
- \\
- \\
- \\
-\end{array}$ \\
\hline $\begin{array}{l}\text { Suborder Miliolida } \\
\text { Indet. species }\end{array}$ & $1 \quad(0.8 \%)$ & - & - \\
\hline $\begin{array}{l}\text { Suborder Lageniina } \\
\text { P. fusuliformis }\end{array}$ & $6(4.6 \%)$ & & \\
\hline Total numbers & 129 & 20 & 5 \\
\hline
\end{tabular}

Table 5. Abundance and diversity of foraminifers in samples from Stns 51502 (April) and 51615 (July)

\begin{tabular}{|c|c|c|c|c|c|c|}
\hline \multirow{2}{*}{$\begin{array}{l}\text { Station/ } \\
\text { Deployment }\end{array}$} & \multirow[t]{2}{*}{ Subsample } & \multicolumn{3}{|c|}{ Sediment fractions only } & \multicolumn{2}{|c|}{ Sediment plus phytodetrital fractions } \\
\hline & & Specimens & Species & $\begin{array}{l}\% \text { Total } \\
\text { meiofauna }\end{array}$ & Specimens & Species \\
\hline \multirow[t]{2}{*}{$51615 / 1$} & a & 427 & 81 & ND & 611 & 83 \\
\hline & $\mathrm{b}$ & 958 & 85 & 68.2 & 1218 & 86 \\
\hline \multirow[t]{3}{*}{$51615 / 4$} & $\mathrm{~b}$ & 172 & 59 & 51.0 & ND & ND \\
\hline & $\mathrm{C}$ & 322 & 87 & 50.2 & ND & ND \\
\hline & $\mathrm{d}$ & 548 & 93 & 61.4 & ND & ND \\
\hline \multirow[t]{2}{*}{$51615 / 5$} & $\mathrm{c}$ & 509 & 79 & 47.4 & 698 & 80 \\
\hline & $d$ & 562 & 91 & 65.3 & 682 & 91 \\
\hline \multirow[t]{2}{*}{$51615 / 6$} & $a$ & 515 & 85 & 58.6 & ND & ND \\
\hline & $\mathrm{b}$ & 250 & 76 & 37.0 & 356 & 78 \\
\hline Mean $\pm S D$ & & $474 \pm 216$ & $82 \pm 10$ & & $713 \pm 281$ & $84 \pm 5$ \\
\hline $51502 / 1$ & $d$ & 412 & 88 & 54.7 & & \\
\hline \multirow[t]{4}{*}{$51502 / 2$} & a & 461 & 87 & 64.5 & & \\
\hline & b & 491 & 94 & 61.1 & & \\
\hline & c & 334 & 81 & 55.7 & & \\
\hline & d & 388 & 92 & 61.9 & & \\
\hline \multirow[t]{2}{*}{$51502 / 6$} & b & 236 & 78 & 54.5 & & \\
\hline & d & 308 & 80 & 61.0 & & \\
\hline $51502 / 8$ & $\mathrm{a}$ & 445 & 89 & 57.6 & & \\
\hline Mean $\pm S D$ & & $385 \pm 79$ & $86 \pm 6$ & & & \\
\hline
\end{tabular}


Table 6. Gross taxonomic composition of foraminiferal populations in samples from Stns 51502 (April) and 51615 (July). Except for the bottom 2 lines, figures are mean percentages $t S D$

\begin{tabular}{|c|c|c|c|c|}
\hline & $\begin{array}{l}\text { Stn } 51502 \\
\text { Sediment }\end{array}$ & $\begin{array}{l}\text { Sediment } \\
\text { fraction }\end{array}$ & $\begin{array}{l}\text { Stn } 51615 \\
\text { Phytodetrital } \\
\text { fraction }\end{array}$ & $\begin{array}{l}\text { Sediment + phyto- } \\
\text { detrital fractions } \\
\text { (Total population) }\end{array}$ \\
\hline Allogromiina & $8.90 \pm 2.30$ & $11.82 \pm 3.01$ & $4.16 \pm 2.41$ & $10.44 \pm 3.11$ \\
\hline $\begin{array}{l}\text { Globigerinacean inhabitants } \\
\text { Agglutinated tubes }\end{array}$ & $8.00 \pm 3.40$ & $3.74 \pm 3.30$ & - & $1.95 \pm 0.50$ \\
\hline (Astrorhizacea) & $2.72 \pm 0.73$ & $3.50 \pm 2.12$ & - & $3.22 \pm 1.90$ \\
\hline Saccamminidae & $30.44 \pm 8.51$ & $21.27 \pm 2.45$ & $0.44 \pm 0.65$ & $14.01 \pm 4.70$ \\
\hline Komokiacea & $2.91 \pm 1.28$ & $1.26 \pm 1.21$ & - & $0.62 \pm 0.59$ \\
\hline \multicolumn{5}{|l|}{ Multilocular } \\
\hline (a) Hormosinacea & $8.18 \pm 3.29$ & $3.29 \pm 1.40$ & - & $2.01 \pm 0.96$ \\
\hline (b) Others & $10.99 \pm 2.95$ & $13.62 \pm 3.27$ & $5.95 \pm 2.11$ & $11.75 \pm 2.02$ \\
\hline \multicolumn{5}{|l|}{ Calcareous forms: } \\
\hline (a) Rotaliina & $24.44 \pm 7.56$ & $39.00 \pm 11.70$ & $87.27 \pm 16.39$ & $53.25 \pm 6.80$ \\
\hline (b) Lagenina & $0.59 \pm 0.34$ & $0.71 \pm 0.34$ & $2.00 \pm 1.67$ & $1.10 \pm 0.23$ \\
\hline (c) Miliolina & $0.63 \pm 0.43$ & $1.22 \pm 0.95$ & - & $1.34 \pm 0.90$ \\
\hline Others & $2.21 \pm 1.15$ & $0.66 \pm 0.65$ & - & $0.31 \pm 0.25$ \\
\hline No. of samples & 7 & 9 & 6 & 5 \\
\hline Total no. of specimens & 2663 & 4263 & 979 & 3565 \\
\hline
\end{tabular}

Group $C$. Eight species which occurred in 4 or more phytodetrital fractions were also significantly more abundant in the total July populations (Table 8); all were ranked among the top 12 July species.

These 23 species are listed in Table 9 together with their abundances in individual samples. For certain species, Table 9 includes additional data from Stns 51502 (Samples 1d and 8b to d) and 51615 (Sample 5b) which were not used in compiling Tables 7 and 8 . With 2 exceptions, the samples taken during April (Stn 51502) and July (Stn 51615) were collected in 2 rather distinct areas, about $1 \mathrm{n}$ mile $(1.85 \mathrm{~km})$ apart. The exceptions are Samples $1 \mathrm{a}$ and $1 \mathrm{~b}$ which were obtained in July at a position close to the April Sample 8a. The data in Table 9 are arranged so that species abundances in these samples can be easily compared (see below).

In addition to these more or less obvious differences in species abundances, the densities of individual species tended to be more variable following phytodetritus deposition. This is shown by the significantly greater variances of 3 abundant species in the total July populations (for Nonionella iridea and Trifarina pauperata $\mathrm{p}=$ 0.1 to $1.0 \%$; for Cassidulina teretis $\mathrm{p}<0.1 \%$ ).

\section{DISCUSSION}

\section{Phytodetritus populations}

Our results from this bathyal site consolidate earlier observations (Gooday 1988a) that seasonally deposited phytodetrital aggregates are occupied by abundant, low diversity populations of benthic foraminifers in the deep-sea. For the reasons discussed above, the Porcupine Seabight assemblages may have been modified by the way in which the samples were collected and processed. However, we are convinced that they are natural assemblages and not artifacts. The single unsieved sample examined (Table 4) suggests that the phytodetritus was, to some extent, mixed with superficial sediment on the core surface, probably through the activities of benthic animals. Hence, the phytodetritus should probably be regarded as part of the sedimentary environment rather than a distinct, suprabenthic microhabitat comparable to that provided, for example, by manganese nodules for encrusting foraminifera (Mullineaux 1987).

These phytodetrital populations could have arisen in several ways (Varon \& Thistle 1988). First, the disproportionate abundance of certain species may develop incidentally from higher rates of dispersion into a habitat initially devoid of benthic organisms (apart from bacteria and flagellates: Lochte \& Turley 1988). Second, these species may colonise the detritus in order to avoid competitors or predators. Third, they may be attracted because the detritus provides a good food source. Only the second and third explanations involve an active response by the foraminifers to the phytodetritus (Varon \& Thistle 1988).

Without careful field and laboratory experiments, such as those conducted by Varon \& Thistle (1988) on harpacticoid copepods from a shallow water marine locality, it is difficult to eliminate any of these possible explanations. Different rates of movement for deep-sea 
Table 7 The 30 most abundant species in samples from Stn 51502 (April) and their corresponding abundances at Stn 51615 (July). Data for the July total populations are derived from Samples $1 \mathrm{a}, 1 \mathrm{~b}, 5 \mathrm{c}, 5 \mathrm{~d}, 6 \mathrm{~b}$; data for the July sediment fractions are derived from Samples $1 \mathrm{a}, 1 \mathrm{~b}, 4 \mathrm{~b}-\mathrm{d}, 5 \mathrm{c}, 5 \mathrm{~d}, 6 \mathrm{a}, 6 \mathrm{~b}, \overline{\mathrm{x}}=$ mean abundance per sample \pm standard deviation; \% $\%$ overall $\%$ of total population. Mean April abundances which are significantly greater than mean July abundances are underlined (p<5\%). See Appendix for full taxonomic names of species

\begin{tabular}{|c|c|c|c|c|c|c|}
\hline \multirow[t]{2}{*}{ Species } & \multicolumn{2}{|c|}{$\operatorname{Stn} 51502$} & \multicolumn{4}{|c|}{ Stn 51615} \\
\hline & $\bar{x} \pm S D$ & $\%$ & $\begin{array}{c}\text { Total } \\
\text { population } \\
\bar{x} \pm \mathrm{SD}\end{array}$ & $\%$ & $\begin{array}{c}\text { Sediment } \\
\text { fraction } \\
\bar{x} \pm S D\end{array}$ & $\%$ \\
\hline Ovammina sp. nov. A & $35.4 \pm 25.0$ & 9.27 & 0 & 0 & 0 & 0 \\
\hline$N$ inidea & $28.9 \pm 10.0$ & 7.55 & $64.8 \pm 34.5$ & 9.11 & $50.9 \pm 32.3$ & 10.76 \\
\hline Lagenammina sp. A & $13.6 \pm 4.0$ & 3.55 & $2.4 \pm 0.8$ & 0.34 & $2.6 \pm 1.0$ & 0.54 \\
\hline ?Nodellum sp. nov. A & $10.4 \pm 10.0$ & 2.73 & $3.8 \pm 3.8$ & 0.53 & $4.7 \pm 3.6$ & 0.97 \\
\hline P. aff. pygmaea & $8.9 \pm 2.1$ & 2.32 & $20.2 \pm 5.2$ & 2.84 & $15.6 \pm 7.2$ & 3.29 \\
\hline C. teretis & $8.6 \pm 7.6$ & 2.24 & $73.4 \pm 79.7$ & 10.32 & $58.4 \pm 65.2$ & 12.36 \\
\hline Crithionina sp. $\mathrm{A}$ & $7.6 \pm 3.9$ & 1.98 & $1.0 \pm 1.1$ & 0.14 & $1.3 \pm 1.3$ & 0.28 \\
\hline T. pauperata & $\overline{7.4 \pm 3.8}$ & 1.94 & $27.6 \pm 13.5$ & 3.88 & $20.3 \pm 14.0$ & 4.30 \\
\hline S. biformis & $7.0 \pm 4.5$ & 1.83 & $7.6 \pm 6.2$ & 1.07 & $8.1 \pm 6.7$ & 1.71 \\
\hline R. micaeceus & $6.3 \pm 3.2$ & 1.65 & $2.2 \pm 1.3$ & 0.31 & $1.8 \pm 0.7$ & 0.38 \\
\hline R. aff. subfusiformis & $\overline{6.1 \pm 4.7}$ & 1.61 & $2.2 \pm 1.2$ & 0.31 & $1.7 \pm 1.7$ & 0.35 \\
\hline L. aff. catenulata & $5.3 \pm 7.7$ & 1.38 & $1.2 \pm 1.9$ & 0.17 & $1.1 \pm 1.6$ & 0.23 \\
\hline A. weddellensis & $5.3 \pm 3.7$ & 1.38 & $145.62 \pm 51.4$ & 20.47 & $17.7 \pm 12.4$ & 3.74 \\
\hline ?Nodellum sp. nov. B & $5.1 \pm 1.5$ & 1.35 & $1.4 \pm 1.4$ & 0.20 & $2.0 \pm 1.9$ & 0.42 \\
\hline G. lobatulus & $5.0 \pm 2.9$ & 1.31 & $22.8 \pm 9.5$ & 3.21 & $13.3 \pm 9.8$ & 2.82 \\
\hline Crithionina sp. B & $5.0 \pm 3.0$ & 1.31 & 0 & 0 & $0.7 \pm 1.7$ & 0.12 \\
\hline Rotaliin sp. M & $4.0 \pm 2.4$ & 1.05 & $2.8 \pm 2.0$ & 0.39 & $2.2 \pm 1.8$ & 0.47 \\
\hline Allogromiin sp. C & $3.7 \pm 2.3$ & 0.97 & $7.8 \pm 4.7$ & 1.10 & $9.3 \pm 6.7$ & 1.97 \\
\hline Lagenammina sp. C & $2.8 \pm 3.4$ & 0.75 & $0.4 \pm 0.8$ & 0.06 & $1.0 \pm 1.6$ & 0.21 \\
\hline Reophax sp. A & $2.8 \pm 2.9$ & 0.75 & $0.2 \pm 0.4$ & 0.03 & $0.3 \pm 1.5$ & 0.05 \\
\hline Rotaliin sp. A & $2.6 \pm 2.7$ & 0.67 & 0 & 0 & $0.7 \pm 1.5$ & 0.14 \\
\hline C. argentea & $2.6 \pm 2.7$ & 0.67 & $0.8 \pm 0.4$ & 0.11 & $1.7 \pm 1.8$ & 0.33 \\
\hline Saccamminid sp. A & $2.4 \pm 4.4$ & 0.64 & 0 & 0 & 0 & 0 \\
\hline Trochamminacean sp. A & $2.3 \pm 2.0$ & 0.60 & $2.0 \pm 1.8$ & 0.28 & $3.1 \pm 2.1$ & 0.66 \\
\hline Reophax sp. B & $2.3 \pm 4.4$ & 0.60 & $1.0 \pm 1.3$ & 0.14 & $0.4 \pm 1.0$ & 0.07 \\
\hline Lagenammina sp. B & $2.3 \pm 1.9$ & 0.60 & $1.0 \pm 1.5$ & 0.14 & $1.1 \pm 1.9$ & 0.23 \\
\hline A. glomeratum & $2.1 \pm 2.3$ & 0.56 & $8.8 \pm 6.2$ & 1.24 & $8.7 \pm 9.2$ & 1.83 \\
\hline Reophax sp. C & $2.1 \pm 3.1$ & 0.56 & $2.2 \pm 2.3$ & 0.31 & $2.0 \pm 1.9$ & 0.42 \\
\hline Saccamminid sp. D & $2.1 \pm 2.9$ & 0.56 & $2.4 \pm 2.1$ & 0.34 & $2.2 \pm 2.3$ & 0.47 \\
\hline Lagenammine sp. D & $2.0 \pm 1.3$ & 0.53 & $4.8 \pm 6.2$ & 0.67 & $3.9 \pm 5.7$ & 0.82 \\
\hline Samples & & 7 & & 5 & & 9 \\
\hline Total numbers & & 2663 & & 3556 & & 4263 \\
\hline
\end{tabular}

foraminifers are likely in view of the 10-fold range of average velocities measured in different shallow water species by Kitazato (1988). Many of the specimens inhabiting phytodetritus are epibenthic, calcareous forms with smooth, rounded shells which probably can move rather rapidly (Kitazato 1988). In contrast, the sediment contains a variety of tubular astrorhizaceans, komokiaceans, and 'Globigerina inhabitants' which, judging from their often complex morphologies, are likely to be more or less immobile and hence incapable of colonising the phytodetritus. Differential rates of colonisation by benthic foraminifers of azoic sediments in experimental trays have been reported by Kaminski et al. (1988).

To some extent, therefore, the composition of the phytodetrital assemblages may reflect the relative mobilities of species living in the sediment. However, there is evidence from BIOTRANS samples that some foraminifers respond directly to phytodetritus. Microorganisms associated with the detritus are injested by Epistominella exigua, Alabaminella weddellensis and Tinogullmia sp. nov. (Gooday 1988a, Gooday \& Turley in press). Moreover, at both our bathyal site, and at the much deeper BIOTRANS site (Gooday \& Turley in press), these 3 species are significantly more abundant in samples containing phytodetritus than they are in samples taken earlier in the year before detritus deposition. Such population fluctuations suggest that phytodetritus triggers a reproductive response in these species. This is consistent with the abundance of small specimens among our phytodetrital populations of $A$. weddellensis (Fig. 2). A similar reproductive response occurs in shallow water and littoral environments where some foraminiferal species undergo rapid popu- 
Table 8 . The 30 most abundant species in the total July populations ( $\operatorname{Stn} 51615$ Samples $1 \mathrm{a}, 1 \mathrm{~b}, 5 \mathrm{c}, 5 \mathrm{~d}, 6 \mathrm{~b}$ ), July sediment fractions (Stn 51615 Samples $1 \mathrm{a}, 1 \mathrm{~b}, 4 \mathrm{~b}-\mathrm{d}, 5 \mathrm{c}, 5 \mathrm{~d}, 6 \mathrm{a}, 6 \mathrm{~b}$ ) and April samples ( $\operatorname{stn} 51502$ ), $\overline{\mathrm{x}}=$ mean abundance per sample \pm standard deviation; $\%=$ overall $\%$ of total population. Species occurring in 4 or more phytodetrital fractions are indicated by an asterisk. Mean July abundances which are significantly greater than mean July abundances are underlined $(p<5 \%)$

\begin{tabular}{|c|c|c|c|c|c|c|}
\hline & \multicolumn{4}{|c|}{ Stn 51615} & \multicolumn{2}{|c|}{ Stn 51502} \\
\hline & \multicolumn{2}{|c|}{ Total population } & \multicolumn{2}{|c|}{ Sediment fraction } & \multirow[b]{2}{*}{$\bar{x} \pm S D$} & \multirow[b]{2}{*}{$\%$} \\
\hline & $\bar{x} \pm S D$ & $\%$ & $\bar{x} \pm S D$ & $\%$ & & \\
\hline - A. weddellensis & $145.6 \pm 51.4$ & 20.47 & $17.7 \pm 12.4$ & 3.74 & $5.3 \pm 3.7$ & 1.38 \\
\hline C. teretis & $73.4 \pm 79.7$ & 10.32 & $58.4 \pm 65.2$ & 12.36 & $8.6 \pm 7.6$ & 2.24 \\
\hline$N$. iridea & $64.8 \pm 34.5$ & 9.11 & $50.9 \pm 32.3$ & 10.76 & $28.9 \pm 10.0$ & 7.55 \\
\hline T. pauperata & $27.6 \pm 13.5$ & 3.88 & $20.3 \pm 14.0$ & 4.30 & $7.4 \pm 3.8$ & 1.94 \\
\hline - E. exigua & $27.2 \pm 19.0$ & 3.82 & $17.2 \pm 15.9$ & 3.64 & $0.3 \pm 0.5$ & 0.07 \\
\hline - Tinogullmia sp. nov. A & $\overline{25.8} \pm 13.5$ & 3.62 & $14.9 \pm 10.6$ & 3.15 & $0.1 \pm 0.3$ & 0.04 \\
\hline - G. lobatulus & $22.8 \pm 9.5$ & 3.21 & $13.3 \pm 9.8$ & 2.82 & $5.0 \pm 2.9$ & 1.31 \\
\hline - Morulaeplecta sp. nov. & $22 . \overline{4} \pm 11.1$ & 3.15 & $12.0=9.0$ & 2.54 & $0.1 \pm 0.3$ & 0.04 \\
\hline - P. aff. pygmaea & $20.2 \pm 5.2$ & 2.84 & $15.5 \pm 7.2$ & 3.29 & $8.9 \pm 2.1$ & 2.32 \\
\hline Allogromiin sp. B & $13.4 \pm 9.9$ & 1.88 & $9.2 \pm 8.8$ & 1.95 & 0 & 0 \\
\hline Adercotryma sp. A & $12.6 \pm 25.2$ & 1.77 & $7.0 \pm 19.8$ & 1.48 & 0 & 0 \\
\hline - Alabaminella sp. A & $10.4 \pm 4.6$ & 1.46 & $0.1 \pm 0.3$ & 0.02 & 0 & 0 \\
\hline "Psammosphaera" sp. nov. A & $9.2 \pm 7.7$ & 1.29 & $11.3 \pm 2.5$ & 2.40 & $0.3 \pm 0.5$ & 0.07 \\
\hline Hyperammina sp. A & $8.8 \pm 5.1$ & 1.24 & $5.5 \pm 5.3$ & 1.17 & $0.1 \pm 0.3$ & 0.04 \\
\hline A. glomeratum & $8.8 \pm 6.2$ & 1.24 & $8.7 \pm 9.2$ & 1.83 & $2.1 \pm 2.3$ & 0.56 \\
\hline Allogromiin sp. C & $7.8 \pm 4.7$ & 1.10 & $9.3 \pm 6.7$ & 1.97 & $3.7 \pm 2.3$ & 0.97 \\
\hline S. biformis & $7.6 \pm 6.2$ & 1.07 & $8.1 \pm 6.7$ & 1.71 & $7.0 \pm 4.5$ & 1.83 \\
\hline - P. fusuliformis & $6.0 \pm 5.1$ & 0.84 & $1.4 \pm 1.3$ & 0.30 & 0 & 0 \\
\hline ?Pelosina sp. & $6.0 \pm 4.2$ & 0.84 & $3.3 \pm 4.3$ & 0.70 & 0 & 0 \\
\hline S. schlumbergeri & $5.6 \pm 4.5$ & 0.79 & $3.7 \pm 4.1$ & 0.78 & $1.0 \pm 0.9$ & 0.28 \\
\hline Lagenammina sp. D. & $4.8 \pm 6.2$ & 0.67 & $3.9 \pm 5.7$ & 0.82 & $2.0 \pm 1.3$ & 0.53 \\
\hline C. pseudungerianus & $4.8 \pm 1.7$ & 0.67 & $3.8 \pm 2.7$ & 0.80 & $1.3 \pm 0.9$ & 0.26 \\
\hline Hyperammina sp. B & $\overline{4.6 \pm 7.7}$ & 0.65 & $2.7 \pm 6.2$ & 0.14 & $0.3 \pm 0.4$ & 0.07 \\
\hline Brizalina sp. A & $4.4 \pm 2.1$ & 0.62 & $3.0 \pm 2.3$ & 0.28 & $1.0 \pm 1.1$ & 0.28 \\
\hline ?Nodellum sp. nov. A & $3.8 \pm 3.8$ & 0.53 & $4.7 \pm 3.6$ & 0.99 & $5.1 \pm 1.4$ & 1.35 \\
\hline Tosaia sp. A & $3.4 \pm 1.0$ & 0.48 & $2.2 \pm 2.3$ & 0.34 & $0.6 \pm 0.7$ & 0.19 \\
\hline Rotaliniin sp. M & $2.8 \pm 2.0$ & 0.39 & $2.2 \pm 1.8$ & 0.47 & $4.0 \pm 2.4$ & 1.05 \\
\hline Brizalina sp. B & $2.4 \pm 2.0$ & 0.34 & $1.4 \pm 1.6$ & 0.30 & $0.3 \pm 0.5$ & 0.07 \\
\hline B. aculeata & $2.4 \pm 0.5$ & 0.34 & $1.7 \pm 1.1$ & 0.35 & $1.3 \pm 1.0$ & 0.34 \\
\hline Lagenammina sp. A & $2.4 \pm 0.8$ & 0.34 & $2.6 \pm 1.0$ & 0.54 & $13.6 \pm 4.0$ & 3.55 \\
\hline Saccamminid sp. D & $2.4 \pm 2.1$ & 0.34 & $2.2 \pm 2.3$ & 0.47 & $2.1 \pm 2.9$ & 0.56 \\
\hline Samples & & 5 & & 9 & & 7 \\
\hline Total specimens & & 3556 & & 4263 & & 2663 \\
\hline
\end{tabular}

lation increases following the sedimentation of phytoplankton blooms (Altenbach 1985, Erskian \& Lipps 1987), and the development of intertidal diatom blooms (Lee et al. 1969).

Gooday (1988a) suggested that foraminiferal species which are disproportionately abundant in the phytodetritus are opportunists. Their life-history strategies may resemble those of the wood-boring xylophagid bivalves which settled as larvae on experimental. wood panels located at $1800 \mathrm{~m}$ off the Bahamas and grew to maturity within 3 mo (Turner 1973). Opportunistic responses by deep-sea organisms to organic inputs will be discussed further by Gooday \& Turley (umpubl.).

There are a number of morphological differences between abyssal and bathyal specimens of phytodetritus-dwelling species (Fig. 3). Bathyal specimens of Alabaminella weddellensis and Epistominella exigua are smaller (mean diameters $88.0 \pm 21.7 \mu \mathrm{m}$ and $73.1 \pm 16.1 \mu \mathrm{m}$, respectively) than those collected in the BIOTRANS area (mean diameters $101.6 \pm 21.7 \mathrm{um}$ and $139.0 \pm 43.9 \mu \mathrm{m}$, respectively). In $\mathrm{A}$. weddellensis the final chamber may be somewhat inflated (Fig. 3C) and fine pustules (ca 1 um diameter) developed over parts of the surface (Fig. 1D), features not apparent in BIOTRANS specimens. In E. exigua the outer edge of the final chamber on the evolute side of the test is fairly straight and entirely obscures the aperture (Figs. 1J, K and $3 \mathrm{E}$ ). whereas this edge bears a triangular projection and only partly obscures the aperture in BIOTRANS specimens (Fig. 3F). Differences between the bathyal and abyssal populations of Tinogullmia sp. nov. are discussed elsewhere (Gooday in press). These differences are not sufficient to separate the populations at the species level. The specimens which we 
Table 9. Species abundances in samples from Stns 51502 (April) and 51615 (July). Group A includes species which are significantly more abundant during April; Group B includes species which are significantly more abundant during July but present only (or mainly) in the sediment fraction; Group $\mathrm{C}$ includes species significantly more abundant during July and consistently present in the phytodetrital fractions. Included are data from Stns 51502 Samples $1 d$, 8b-d and Stn 51615 Sample 5b which were sorted for selected species only. For Group C species, data are given only for samples where foraminifers were extracted from the phytodetrital fractions. -: no data

\begin{tabular}{|c|c|c|c|c|c|c|c|c|c|c|c|c|c|c|c|c|c|c|c|c|c|}
\hline \multirow[t]{2}{*}{ Species } & \multicolumn{11}{|c|}{ Stn 51502} & \multicolumn{10}{|c|}{ Stn 51615} \\
\hline & $1 d$ & $2 a$ & $2 b$ & $2 c$ & $2 d$ & $6 b$ & $6 \mathrm{~d}$ & $8 \mathrm{a}$ & $8 \mathrm{~b}$ & $8 \mathrm{C}$ & $8 \mathrm{~d}$ & $1 \mathrm{a}$ & $1 \mathrm{~b}$ & $4 b$ & $4 \mathrm{C}$ & $4 \mathrm{~d}$ & $5 b$ & $5 c$ & $5 \mathrm{~d}$ & $6 a$ & $6 b$ \\
\hline \multicolumn{22}{|l|}{ Group A } \\
\hline Crithionina sp. A & - & 13 & 11 & 9 & 4 & 4 & 2 & 10 & - & - & - & 3 & 0 & 2 & 0 & 1 & - & 1 & 0 & 4 & 1 \\
\hline Lagenammina sp. A & - & 21 & 14 & 11 & 15 & 10 & 8 & 6 & - & - & - & 3 & 1 & 3 & 2 & 3 & 2 & 3 & 2 & 3 & 3 \\
\hline Ovammina sp. nov. A & - & 69 & 68 & 15 & 52 & 24 & 4 & 16 & 3 & 11 & 2 & 0 & 0 & 0 & 0 & 0 & - & 0 & 0 & 0 & 0 \\
\hline R. micaceus & - & 9 & 5 & 5 & 4 & 3 & 5 & 13 & 0 & 1 & 1 & 0 & 4 & 2 & 0 & 1 & 1 & 1 & 0 & 4 & 1 \\
\hline Saccamminid sp. A & - & 1 & 0 & 0 & 3 & 0 & 0 & 13 & - & - & - & 0 & 0 & 0 & 0 & 0 & - & 0 & 0 & 0 & 0 \\
\hline \multicolumn{22}{|l|}{ Group B } \\
\hline Adercotryma sp. A & - & 0 & 0 & 0 & 0 & 0 & 0 & 0 & - & - & - & 0 & 63 & 0 & 0 & 0 & - & 0 & 0 & 0 & 0 \\
\hline Allogromiin sp. B & - & 0 & 0 & 0 & 0 & 0 & 0 & 0 & - & - & - & 2 & 25 & 5 & 1 & 7 & - & 23 & 3 & 15 & 2 \\
\hline C. teretis & 11 & 5 & 8 & 8 & 9 & 1 & 2 & 26 & 16 & 1 & 0 & 57 & 226 & 10 & 26 & 102 & 41 & 22 & 47 & 27 & 9 \\
\hline C. pseudungerianus & 5 & 3 & 0 & 1 & 1 & 2 & 1 & 1 & 2 & 1 & 0 & 6 & 5 & 0 & 1 & 1 & 3 & 4 & 7 & 8 & 3 \\
\hline N. iridea & 43 & 16 & 34 & 27 & 33 & 11 & 40 & 39 & 23 & 5 & 8 & 46 & 115 & 17 & 16 & 63 & 5 & 49 & 92 & 39 & 21 \\
\hline Hyperammina sp. A & - & 0 & 0 & 1 & 0 & 0 & 0 & 0 & - & - & - & 8 & 10 & 1 & 0 & 3 & - & 17 & 8 & 2 & 1 \\
\hline Psammosphaera sp. nov. A & - & 0 & 0 & 1 & 0 & 0 & 0 & 1 & - & - & - & 10 & 1 & 6 & 19 & 10 & 12 & 9 & 23 & 21 & 3 \\
\hline ? Pelosina sp. & - & 0 & 0 & 0 & 0 & 0 & 0 & 0 & - & - & - & 3 & 9 & 0 & 0 & 12 & - & 0 & 0 & 0 & 6 \\
\hline Tosaia sp. A & - & 1 & 1 & 0 & 0 & 1 & 2 & 0 & - & - & - & 5 & 3 & 0 & 2 & 1 & - & 4 & 3 & 0 & 2 \\
\hline T. pauperata & - & 5 & 15 & 6 & 7 & 2 & 10 & 7 & - & - & - & 21 & 52 & 1 & 10 & 23 & - & 27 & 27 & 11 & 11 \\
\hline \multicolumn{22}{|l|}{ Group C } \\
\hline Tinogullmia sp. nov. A & - & 0 & 0 & 0 & 1 & 0 & 0 & 0 & 0 & 0 & 1 & 29 & 45 & - & - & - & 25 & 12 & 34 & - & 10 \\
\hline E. exigua & - & 0 & 0 & 1 & 0 & 0 & 0 & 1 & 0 & 1 & 0 & 28 & 63 & - & - & - & 11 & 15 & 21 & - & 9 \\
\hline A. weddellensis & - & 3 & 7 & 7 & 3 & 2 & 13 & 2 & - & - & - & 146 & 238 & - & - & - & 100 & 152 & 108 & - & 89 \\
\hline G. lobatulus & - & 3 & 7 & 4 & 11 & 3 & 2 & 5 & - & - & - & 18 & 39 & - & - & - & 12 & 24 & 23 & - & 10 \\
\hline Morulaeplecta sp. nov. A & - & 0 & 0 & 1 & 0 & 0 & 0 & 0 & - & - & - & 20 & 44 & - & - & - & 9 & 24 & 18 & - & 8 \\
\hline P. aff. pygmaea & - & 6 & 13 & 9 & 10 & 9 & 8 & 7 & - & - & - & 21 & 27 & - & - & - & 9 & 21 & 21 & - & 11 \\
\hline ? Alabaminella sp. A & - & 0 & 0 & 0 & 0 & 0 & 0 & 0 & - & - & - & 6 & 15 & - & - & - & 7 & 15 & 12 & - & 6 \\
\hline P. fusuliformis & - & 0 & 0 & 0 & 0 & 0 & 0 & 0 & - & - & - & 4 & 6 & - & - & - & 1 & 4 & 2 & - & 3 \\
\hline
\end{tabular}

assign to E. exigua differ from E. vitrea, the shallowwater counterpart of E. exigua, in having 5 rather than 6 to $6 \frac{1}{2}$ chambers in the final whorl (Todd \& Low 1967). The rather more inflated later chambers in $A$. weddellensis, and the smaller size of E. exigua, may indicate that the bathyal site is a stressful environment for these species, perhaps because it lies near the limit of their bathymetric ranges (Boltovskoy \& Wright 1976, p. 91, Wang \& Lutze 1986). Weston (1985) found that $E$. exigua only became the dominant species in the dead foraminiferal assemblage in the Porcupine Seabight below about $2400 \mathrm{~m}$.

The occurrence, albeit occasionally, of the allogromiin Tinogullmia sp. nov. inside small crustacean (copepod) moults (Table 4 ) is of interest. These structures are small enough $(<1 \mathrm{~mm})$ to fall within the operational range (ambit) of individual foraminifers. They probably provide refuges stocked with large populations of bacteria on which Tinogullmia appears to feed (Gooday \& Turley in press). Some allogromiin and saccamminid foraminifers, as well as nematodes, seek refuge inside empty Globigerina tests (Gooday
1984). Jumars (1976) illustrated a presumed faecal pellet $(1.5 \mathrm{~cm}$ long) from the Santa Catalina Basin which provided a microhabitat for encrusting entoprocts and an agglutinated foraminifer. Moults, and other small organic remains, represent pockets of organic enrichment which contribute towards the small-scale (centimetre to submillimetre) fabric of the sedimentary environment and thereby probably help to maintain high levels of diversity among meiofaunal taxa such as the Foraminifera. Grassle \& Morse-Porteous (1987) and Grassle (1989) have recently emphasized the decisive role played by somewhat larger (millimetre to metre sized) organic patches in the maintainance of high macrofaunal diversity in deep-sea sediments.

\section{Total and sediment populations}

Total foraminiferal population densities were higher in July, when phytodetritus was present, than in April (Table 4), but not significantly so. However, the total population densities were significantly more variable 

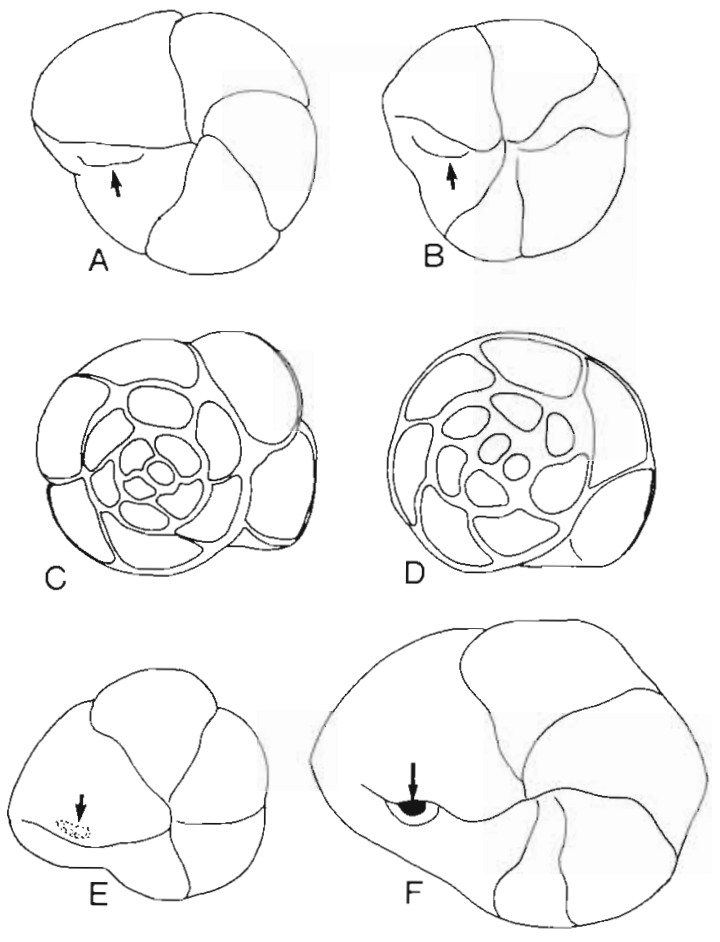

Fig. 3. (A), (B) Alabaminella weddellensis, involute side (apertural flap arrowed). (C), (D) A. weddellensis, evolute side. (D). (F) Epistominella exigua, involute side; aperture (arrowed) is completely obscured by edge of final chamber in (E) but only partly obscured in (F). (A), (C), (E) are from Stn 51615 $(1340 \mathrm{~m}) ;(B),(D),(F)$ are from a BIOTRANS sample $(4450 \mathrm{~m})$. Scale bar $=100 \mu \mathrm{m}$

in the July samples. There were also some significant differences in the abundance and variance of species in the total populations (Tables 7 to 9). Patchy distributions of benthic foraminiferal populations are well documented in both shallow water (Buzas 1968, 1970, Lee et al. 1969, Matera \& Lee 1972, Bernhard 1987. Hohenegger et al. 1989) and the deep-sea (Bernstein et al. 1978, Bernstein \& Meador 1979, Kaminski 1985). Such spatial heterogeneity may have contributed to at least some of the differences observed between the April and July assemblages. For example, 3 species (Adercotryma sp. A, Pelosina sp. saccamminid sp. A) occurred in only a few samples (Table 9, Groups A, B) and seem to display obvious spatial patchiness. On the other hand, the significantly greater abundance in the July samples of 8 phytodetritus-dwelling species (Group $\mathrm{C}$ in Table 9 ) is more likely to be a seasonal phenomenon related to phytodetrital deposition. These species are all ranked among the top 12 in the July total population (Table 8). Note that they are consistently more numerous in Samples $1 \mathrm{a}$ and $1 \mathrm{~b}$ (July) than in Sample 8a (Table 9), which was taken in the same area during April (see above). This indicates that spatial heterogeneity alone is unlikely to account for differ- ences in their abundances. The increased abundance in the July samples of Alabaminella weddellensis the dominant species of the phytodetrital fractions) is particularly striking (Tables 8 and 9).

Ovammina sp. nov. A has a different pattern of abundance. It is the top ranked species in the Apri] samples but is entirely absent from July samples (Table 7). This pattern, which is the inverse of that displayed by phytodetritus-dwelling (Group C) species, could have arisen by chance from spatial variability. Another possible explanation is that Ovammina sp. is out-competed during summer by seasonally abundant species. Muller (1975) described saltmarsh foraminiferal communities in which Allogromia laticollaris Arnold, normally a rare species, became abundant when populations of the dominant species declined. Some of the less abundant species present in our samples, for example Spiroplectammina biformis, seem to maintain fairly stable populations irrespective of whether phytodetritus is present or absent (Tables 7 and 8). Thus, deep-sea foraminifers may display a range of life-history strategies and population dynamics comparable to those of their shallow-water relatives (Erskian \& Lipps 1987 ).

Cassidulina teretis is the top-ranked species in the July sediment fractions and is significantly $(p<0.1 \%)$ more abundant in the total July populations than in the April samples (Tables 7 and 8). These July populations are dominated by small individuals (Fig. 2). Out of 361 specimens ranging in diameter from 45 to $245 \mu \mathrm{m}$, almost half were $<106 \mu \mathrm{m}$ and three-quarters $<145 \mu \mathrm{m}$. This size distribution suggests that, like some phytodetritus-dwelling species (see above), $C$. teretis may be actively reproducing during July However, this species occurred only rarely in the phytodetritus (probably as a contaminant) and is almost certainly a sediment-dweller. Its apparent reproductive response may be linked to a relative abundance of food in the form of large bacterial populations. Bacterial densities are known to be higher in sediment beneath phytodetritus than in sediment collected before phytodetritus deposition (Thiel et al. in press). The distribution of $C$. teretis was also very patchy in July, a disproportionate number of specimens being present in a few samples (Table 9). This pattern suggests that $C$. teretis may reproduce most vigorously in localized areas where lood (probably bacteria) is concentrated. Correlations between the small-scale distributions of benthic foraminifers and their probable food (cyanobacteria and diatoms) have been established in the intertidal North Adriatic (Hohenegger et al. 1989)

Sediment-dwelling species which are abundant in the July samples, for example Cassidulina teretis, 'Psammosphaera' sp. nov, and Trifarina pauperata, probably live on or within the soft, flocculent surface 
sediment immediately beneath the detrital layer. One of these species, $T$. pauperata, is closely allied taxonomically and morphologically to the genus Uvigerina. Zahn et al. (1986, p. 38) suggested that the test morphology of Uvigerina species may indicate a near surface infaunal habitat - with a preference for the decaying 'soup' of organic matter on the sea-floor' (see also Altenbach \& Sarnthein 1989). Deep-sea foraminiferal species therefore may display a fine-scale pattern of vertical zonation just below the sediment surface, in addition to the broader, centimetre-scale patterns described by Corliss (1985) and Gooday (1983, 1986).

\section{CONCLUSIONS}

(1) Seasonally deposited aggregates of phytodetritus provide a microhabitat for some benthic foraminiferal species at depths of around $1350 \mathrm{~m}$ in the northeast Atlantic. The most abundant inhabitant is Alabaminella weddellensis; others include Epistominella exigua and Tinogullmia sp. nov. The same species were found also in phytodetrital aggregates from the much deeper (4550 m) BIOTRANS site (Gooday 1988a).

(2) Certain species, including those which inhabit the phytodetritus, are significantly more abundant in the total (phytodetrital plus sediment) July populations than in the April populations. Others are either more abundant during April or display no significant fluctuations in abundance. These results suggest that some foraminiferal species respond opportunistically to phytodetritus while others react negatively or not at all

Acknowledgements. We thank Drs M. V. Angel and A. L. Rice for critically reading the manuscript. Prof. P. Brönnimann and Dr R. W. Jones for taxonomic guidance, Dr R. S. Lampitt for the gift of a sample, Dr J. A. Whittaker for access to the British Museum (Natural History) collections, Mr M. D. Conquer for carefully printing the photographs, Miss P. E. Williamson for preparing Fig. 2 and Mrs P. H. Talbot for secretarial assistance.

\section{LITERATURE CITED}

Aller, J. Y., Aller, R. C. (1986). Evidence for localized enhancement of biological activity associated with tube and burrow structures in deep-sea sediments at the HEBBLE site. western North Atlantic. Deep Sea Res. 33: 755-790

Altenbach, A. V. (1985). Die Biomasse der benthischen Foraminiferen: Auswertungen von 'Meteor'-Expeditionen im Östlichen Nordatlantik. Ph.D. thesis, ChristianAlbrechts-Universität, Kiel

Altenbach, A. V., Sarnthein, M. (1989). Productivity record in benthic Foraminifera. In: Berger, W H., Smetacek, V S., Wefer, G. (eds.) Productivity of the oceans: present and past. John Wiley \& Sons Ltd, Chichester, p. 255-269

Angel, M. V. (1984). Detrital fluxes through pelagic ecosystems. In: Fasham, M. J. R. (ed.) Flows of energy through pelagic ecosystems. NATO Conference Series. Series IV. Marine sciences. Plenum Press, New York, p. 475-516
Appendix. Full names and authorships of species included in Tables 7 to 9

Adercotryma glomeratum (Brady 1878)

Alabaminella weddellensis (Earland 1936)

Bulimina aculeata d'Orbigny 1826

Cassidulina teretis Tappan 1951

Cibicides pseudungerianus (Cushman 1922)

Cystammina argentea Earland 1934

Epistominella exigua (Brady 1884)

Gavinulinopsis lobatulus (Parr 1950)

Leptohalysis aff. catenulata (Höglund 1947)

Nonionella iridea Heron-Allen \& Earland 1932

Parafissurina fusuliformis (Loeblich \& Tappan 1953)

Portatrochammina aff. pygmaea (Höglund 1947)

Reophax micaceus Earland 1934

Reophax aff. subfusiformis Earland 1933

Sigmoilina schlumbergeri Silvestri 1904

Spiroplectammina biformis (Parker \& Jones 1865)

Trifarina pauperata (Heron-Allen \& Earland 1932)

Barnett, P. R. O., Hardy, B., Watson, J. (1982). Meiofaunal studies in the Rockall Trough. Deep-sea Newsletter 6: 5

Barnett, P. R. O., Watson, J., Connelly, D. (1984). A multiple corer for taking virtually undisturbed samples from shelf, bathyal and abyssal sediments. Oceanologica Acta 7: $399-408$

Bernhard, J. M. (1987). Foraminiferal biotopes in Explorers Cove, McMurdo Sound, Antarctica. J. foram. Res. 17 $286-297$

Bernhard, J. M. (1988). Postmortem vital staining in benthic Foraminifera: duration and importance in population and distributional studies. J. foram. Res. 18: 143-146

Bernstein, B. B., Hessler, R. R., Smith, R., Jumars, P. A. (1978). Spatial dispersion of benthic Foraminifera in the abyssal central North Pacific. Limnol. Oceanogr 23: 401-416

Bernstein, B. B., Meador, J. P. (1979). Temporal persistence of biological patch structure in an abyssal benthic community. Mar. Biol. 51: 179-183

Billett, D. S. M., Lampitt, R. S., Rice, A. L., Mantoura, R. F. C. (1983). Seasonal sedimentation of phytoplankton to the deep-sea benthos. Nature, Lond. 302: 520-522

Billett, D. S. M., Llewellyn, C., Watson, J. (1988). Are deep-sea holothurians selective feeders? In: Burke. R. D., Mladenov, P. V., Lambert, P., Parsley, R. L. (eds.) Echinoderm Biology: Proceedings of the Sixth Echinoderm Conference, Victoria, 23-28 August 1987. A. A. Balkema, Rotterdam, p. 421-429

Boltovskoy, E., Lena, H. (1970). On the decomposition of the protoplasm and the sinking velocity of the planktonic foraminifers. Int. Revue ges. Hydrobiol 55: 797-804

Boltovskoy, E., Wright, R. (1976). Recent Foraminifera. W Junk, The Hague

Brady, H. B. (1884). Report on the Foraminifera dredged by H. M. S. Challenger during the years 1873-1986. Rept. Scientific Results Explor. Voyage H. M. S. Challenger, Zoology 9: 1-814, 115 pls

Bruland, K. W., Beinfang, P. K, Bishop, J. K. B., Eglinton, G., Ittekkot, V A. W., Lampitt, R., Sarnthein, M., Theide, J., Walsch, J. J., Wefer, G. (1989). Group Report. Flux to the seafloor. In: Berger, W. H., Smetacek, V S., Wefer, G. (eds.) Productivity of the ocean: present and past. John Wiley \& Sons Ltd, Chichester, p. 193-215

Buzas, M. A. (1968). On the spatial distribution of Foraminifera. Contr. Cushman Fdn toramin. Res. 19: 1-11

Buzas, M. A. (1970). Spatial homogeneity statistical analyses 
of unispecies and multispecies populations of Foraminifera. Ecology 51. 874-879

Corliss, B. H. (1985). Microhabitats of benthic foraminifera within deep-sea sediments. Nature, Lond. 314: 435-438

Earland, A. (1936). Foraminifera. Part IV Additional records from the Weddell Sea sector from material obtained by the S.Y 'Scotia' 'Discovery' Reps. 10: 1-76, pls 1-2

Erskian, M. G., Lipps, J. H. (1987). Population dynamics of the foraminiferan Glabratella ornatissima (Cushman) in northern California. J. foram. Res. 17. 240-256

Fowler, S. W., Knauer, G. A. (1986). Role of large sinking particles in the transport of elements and organic compounds through the water column. Prog. Oceanogr. 16: 147-194

Gardener, W. D., Sullivan, L. G., Thorndike, E. M. (1984). Long-term photographic, current, and nephelometer observations of manganese nodule environments in the Pacific. Earth Planet. Sci. Lett. 70: 95-109

Gooday, A. J. (1983). The vertical distribution of Foraminifera within the sediment: preliminary results from the bathyal Porcupine Seabight. Deep-Sea Newsletter 8: 5-8

Gooday, A. J. (1984). Records of deep-sea Rhizopod tests inhabited by metazoans in the north-east Atlantic. Sarsia 69: 45-53

Gooday, A. J. (1986). Meiofaunal foraminiferans from the bathyal Porcupine Seabight (northeast Atlantic); size structure, standing stock, taxonomic composition, species diversity and vertical distribution in the sediment. Deep Sea Res. 33: 1345-1373

Gooday, A. J. (1988a). A response by benthic Foraminifera to the deposition of phytodetritus in the deep-sea. Nature, Lond. 332: 70-73

Gooday, A. J. (1988b). Phylum Sarcomastigophora. In: Higgins, R., Thiel, H. (eds.) An introduction to the study of meiofauna. Smithsonian Institution Press, Washington, D.C., p. $243-257$

Gooday, A. J. (in press). Tinogullmia riemanni sp. nov. (Allogromiina; Foraminiferida), a new species associated with organic detritus in the deep-sea. Bull. Br. Mus. nat. Hist. (Zool.)

Gooday, A. J., Turley, C. M. (in press). Responses by benthic organisms to inputs of organic material to the ocean floor: a review. Phil. Trans. R. Soc. Lond.

Grassle, J. F. (1989). Species diversity in deep-sea communities. Trends Ecol. Evol. 4: 12-15

Grassle, J. F., Morse-Porteous, L. S. (1987). Macrofaunal colonization of disturbed deep-sea environments and the structure of deep-sea benthic communities. Deep Sea Res. 34: 1911-1950

Heron-Allen, E., Earland, A. (1932). Foraminifera. Part 1 The ice-free area of the Falklands and adjacent seas. 'Discovery Reps. 4: 291-460

Hohenegger, J., Piller, W., Baal, C. (1989). Reasons for spatial microdistributions of foraminifers in an intertidal pool (northern Adriatic Sea). P.S.Z N.I. Mar. Ecol, 10: 43-78

Jones, R. W (1984). A revised classification of the unilocular Nodosariida and Buliminida (Foraminifera). Rev. esp. Micropaleont. 16: 91-160

Jumars, P. A. (1976). Deep-sea diversity: does it have a characteristic scale? J. mar Res. 34: 217-246

Kaminski. M. A. (1985). Evidence for the control of abyssal agglutinated foraminiferal communty structure by substrate disturbance: results from the HEBBLE area. Mar Geol. 66: 113-131

Kaminski, M. A., Grassle, J. F., Whitlach, R. B. (1988). Life history and recolonization amoung agqlutinated Foraminifera in the Panama Basin. In: Rögl, F., Gradstein, F. M. (eds.) Proceedings Second Workshop on Agglutinated Foraminifera, Vienna 1986. Abhandlungen der Geologischen Bundesanstalt 41.229-243

Kitazato, H. (1988). Locomotion of some benthic foraminifera in and on sediments. J. foram. Res. 18: 344-349

Lampitt, R. S. (1985). Evidence for the seasonal deposition of detritus to the deep-sea floor and its subsequent resuspension. Deep Sea Res. 32: 885-897

Lee, J. J., Muller, W. A., Stone, R. J., McEnery, M. E., Zucker, W. (1969). Standing crop of foraminifera in sublittoral epiphytic communities of a Long Island salt marsh. Mar. Biol. 4: 44-61

Lochte, K., Turley, C. M. (1988). Bacteria and cyanobacteria associated with phytodetritus in the deep sea. Nature. Lond. 333: 67-69

Loeblich, A. R., Tappan, H. (1953). Studies of Arctic Foraminifera. Smithson. misc. Collns 121: 1-150

Loeblich, A. J., Tappan, H. (1988). Foraminiferal genera and their classification. Van Nostrand Reinhold Company, New York (2 Vol)

Mackensen, A., Hald, M. (1988). Cassidulina teretis Tappan and C. laevigata d'Orbigny: their modern and late Quaternary distribution in northern seas. J. foram. Res. 18: 16-24

Matera, N. J., Lee, J. J. (1972). Environmental factors affecting the standing crops of foraminifera in sublittoral and psammolittoral communities of a Long Island salt marsh. Mar Biol. 14: 89-103

Muller, W. A. (1975). Competition for food and other nicherelated studies of three species of salt marsh Foraminifera. Mar. Biol. 31: 339-351

Mullineaux, L. S. (1987). Organisms living on manganese nodules and crusts: distribution and abundance at three North Pacific sites. Deep Sea Res. 34: 165-184

Parr, W. J. (1950). Foraminifera. B.A.N.Z. Antarctic Research Expedition, 1929-1931, report series B 5: 232-392, pls 1-15

Rice, A. L., Billett, D. S. M., Fry, J., John, A. W. G., Lampitt, R. S., Mantoura, R. F. C., Morris, R. J. (1986). Seasonal deposition of phytodetritus to the deep sea floor. Proc. R. Soc Edinb. 88B: 265-279

Riemann, F. (1989). Gelatinous phytoplankton detritus aggregates on the Atlantic deep-sea bed. Structure and mode of formation. Mar. Biol. 100: 533-539

Sibuet, M. (1984). Quantitative distribution of echinoderms (Holothuroidea, Asteroidea, Ophiuroidea, Echinoidea) in relation to organic matter in the sediment in the deep basins of the Atlantic Ocean. In Keegan, B. F., O'Connor, B. D. S. (eds.) Echinodermata: Proceedings of the 5th International Echinoderm Conference, Galway. A. A. Balkema, Rotterdam, p. 99-108

Sibuet, M. (1.987). Structure des peuples benthique en relation avec les conditions trophic en milieu abyssal dans l'océan Atlantique. Thèse de Doctorat d'État ès Sciences Naturelles. Université Pierre et Marie Curie

Takahashi, K. (1986). Seasonal fluxes of pelagic diatoms in the subarctic Pacific, 1982-1983. Deep Sea Res. 33: 1225-1251

Tappan, H. (1951). Northern Alaskan index foraminifera. Contr. Cushman Fdn foramin. Res. 2: 1-8

Thiel, H., Lochte, K., Gooday, A. J., Hemleben, C., Mantoura. R. F. C., Patching, J. W., Ptannkuche, O., Riemann, F., Schriever, G., Turley, C. M. (in press). Phytodetritus on the deep-sea floor in a central oceanic region of the northeast Atlantuc. Biol. Oceanogr

Todd, R, Low, D. (1967). Recent Foraminifera from the Gulf of Alaska and southeastern Allaska. U.S. Geol. Survey Prof. Paper 573-A: 1-46. pls 1-5

Turner, R. D. (1973). Wood-boring bivalves, opportunistic species in the deep-sea. Science 180: 1377-1379 
van der Zwaan, G. J. (1980). The impact of climatic changes on the deep sea benthos. K. Ned. Akad. Wet.-Proc. B83 379-397

Varon, R., Thistle, D. (1988). Response of a harpacticoid copepod to a small-scale natural disturbance. J. exp. mar Biol. Ecol. 118: 245-256

Wang, P. Lutze, G. F. (1986). Inflated later chambers ontogenetic changes of some Recent hyaline benthic Foraminifera. J. foram. Res. 16: 48-62

Ward, B. L., Webb, P.-N. (1986). Late Quaternary foraminifera

This article was submitted to the editor from raised deposits of the Cape Royds-Cape Barne area Ross Island, Antarctica. J. foram. Res. 16: 176-200

Weston, J. F. (1985). Comparison between Recent benthic foraminiferal faunas of the Porcupine Seabight and Western Approaches continental slope. J. Micropalaeontol. 4 165-183

Zahn, R., Winn, K., Sarnthein, M. (1986). Benthic foraminiferal $\delta 13 \mathrm{C}$ and accumulation rates of organic carbon: Uvigerina peregrina groups and Cibicidoides wuellerstorfi. Paleoceanography 1: 27-42

Manuscript first received: March 28, 1989

Revised version accepted: July 26, 1989 